\title{
The problem of Taeniasis and Cysticercosis in Irian Jaya, Indonesia
}

\author{
Sri Surastuti Margono*, Akira Ito",Thomas Suroso ${ }^{f}$
}

\begin{abstract}
Abstrak
Penyakit yang disebabkan Taenia solium dewasa dan larva, menyebar ke arah barat Irian Jaya sampai melintasi batas Indonesia ke Papua New Gini. Dua puluh Puskesmas melaporkan 638 dan 945 kasus baru dengan gejala epilepsi, berturut-turut pada tahun $1994-$ 1995. Kuesioner terhadap 31 responden mendapatkan $83.9 \%$ buta huruf, $93.6 \%$ petani dan semua responden kadang-kadang makan daging babi; tidak pernah makan daging lain. Di daerah ini tidak ada sumber air minum bersih dan juga tidak ada fasilitas sanitasi. Babi berkeliaran di sekitar rumah, jarang dikandangkan. Setelah kerjasama dengan berbagai pihak antara lain dengan Asahikawa Medical College, Jepang dapat diperiksa 49 sampel serum dengan immunoblot yang menghasilkan $67 \%$ kasus dengan gejala kejang epilepsi dan $65 \%$ dengan benjolan subkutan positif terhadap sistiserkosis. Aktivitas penduduk ke daerah lain, higiene perorangan dan lingkungan, pentingnya babi dalam kehidupan masyarakat merupakan beberapa hal yang menyebabkan taeniasis dan sistiserkosis merupakan masalah penting di daerah ini. (Med J Indones 2001; 10:110-4)
\end{abstract}

\begin{abstract}
The disease, caused by the adult and larva of Taenia solium, spread to the western part of Irian Jaya crossing the border of Indonesia to Papua New Guinea. Twenty local health centers reported 638 and 945 new cases with epileptic seizures in 1994 and 1995 respectively. Questionnaires were distributed to 31 respondents with results as follows: $83.9 \%$ were illiterate, $93.6 \%$ farmers and all of them sometimes ate not well-cooked pork; no other meat was consumed. In this area no healthy drinking water was available; also there was no sanitary facilities. Pigs were roaming around the houses, rarely the pigs were put behind fences. After international collaboration with several institutions, e.g with Asahikawa Medical College, Japan, 29 serum samples were examined by immunoblot with positive results for $67 \%$ of the cases suffering from epileptic seizures and $65 \%$ with subcutaneous nodules. Moving of people to other areas personal and environmental hygiene, the importance of pigs in the daily life of the community were important issues in maintaining the disease being caused by $T$. solium in this area. (Med J Indones 2001; 10:110-4)
\end{abstract}

Keywords: Taenia solium, Irian Jaya, spreading, international collaboration

Cases of taeniasis and cysticercosis in Irian Jaya, a province of Indonesia were reported for the first time in Enarotali, Paniai District. Among 170 hospitalized patients $9 \%$ were found positive with Taenia eggs. Thirteen cases suffering from cysticercosis were reported during 6 months in $1972-1973^{1,2}$. Subianto et $\mathrm{al}^{3}$ found that many patients with burns also suffered from epileptic seizures, probably caused by a number of cysticerci located in the brains. A serological survey revealed a correlation between symptoms and seropositive results. ${ }^{4}$

\footnotetext{
* Department of Parasitology, Faculty of Medicine, University of Indonesia, Jakarta, Indonesia

* Department of Parasitology, Asahikawa Medical College. Asahikawa, Japan

${ }^{f}$ Directorate General of Communicable Disease Control and Environmental Health, Ministry of Health and Social Welfare, Jakarta, Indonesia
}

Cases with epileptic seizures were increasing in Assologaima Subdistrict, Jayawijaya District. In 1991 only 4 cases among a population number of 13334 were reported, whereas in 1995, with a population number of 17493,145 cases were recorded.

The disease was spreading from the western to the eastern part of Papua already crossing the border of Indonesia into Papua New Guinea. Besides the high mobility of people, the level of personal hygiene and environmental hygiene in these areas should be considered as parts of the problem. Important issues such as behavior of the people in the way of keeping their pigs and consuming not well-cooked pork are important aspects in causing the high endemicity of the disease.

The diagnosis of the disease, treatment and health education create many difficulties. Manpower and 
budget are limited for the control of taeniasis and cysticercosis.

\section{DESCRIPTION OF LOCATION}

Paniai District is located in the Kamu Valley, the western part of the central highlands of Irian Jaya. The altitude ranges from $1400-1800 \mathrm{~m}$ above sealevel. There are three lakes in this valley: Paniai, Tage and Tigi Lake.

The district of Jayawijaya is located in the eastern part of Irian Jaya. The altitude is between $600 \mathrm{~m}$ to more than $3000 \mathrm{~m}$ above sea-level. Low and high mountains are found in this area with fertile, wide spread valleys. For most areas the climate is tropical hot and humid, the temperature varies between 12$28^{\circ} \mathrm{C}$, with much rain, average $190 \mathrm{~mm} /$ month.

\section{TAENIASIS AND CYSTICERCOSIS IN IRIAN JAYA}

The first cases suffering from taeniasis were reported after stool examinations revealed $9 \%$ of 170 hospitalized patients positive for Taenia eggs. The method used for the stool examinations was the formal-ether method ${ }^{6}$. Stool samples from several patients were examined more than once. ${ }^{1}$

During a period of 6 months in 1972-1973, 13 cases suspected with cysticercosis were diagnosed at the Enarotali hospital, Paniai District. The patients consisted of 5 women and 8 men ranging in age from 16 to 40 years. Seven patients suffered from loss of consciousness and general convulsions from 1-3 times a week. These seven patients complained of headache and or dizziness. Two among the 7 patients had personality changes, which was reported by their relatives. Complaints on disturbances of the eyes, such as blurred vision, photophobia and diplopia were found in six patients. Palpable cysticercus nodules in the 13 patients were mostly located in the biceps muscle region ( 9 cases). Other location of palpable cysticercus nodules were in the region of the forearm, region of the lateral portion of the major pectoral muscle, region of the deltoid muscle, neck, abdominal wall and near the mouth. Several subcutaneous nodules were removed and diagnosed as cysticerci of Taenia solium. ${ }^{2}$
Clinical signs and symptoms by age, of 318 inhabitants of the Obano village, south-west of the Paniai Lake, who were interviewed and examined, by Desowitz et $\mathrm{al}^{4}$ are shown in Table 1. It was found that none of the sixty-six children between the age of $0-4$ years had any signs or symptoms. Only one among the forty children, aged 5-9 years had epileptic seizures $(2.5 \%)$. One among 11 children in the age group of 10-14 years had epileptic seizures $(8.3 \%)$ and $1(7.1 \%)$ among 13 individuals in the age group 15-19 years suffered from seizures and cysts. In the age group of 20-50 years, consisting of 186 persons, eighty-six persons had signs and symptoms. Epileptic seizures were found in 39 cases $(21.0 \%), 6$ cases had seizures as well as subcutaneous nodules, whereas 5 cases had only palpable cysts. Thirty cases $(16.1 \%)$ complained of headache and 6 cases of "weakness" or pain $(3.2 \%)$.

Table 1. Clinical data and serological results (CIEP) of 125 serum samples in Obano, Paniai District

\begin{tabular}{lcc}
\hline & Number & $\begin{array}{c}\text { Seropositive } \\
(\%)\end{array}$ \\
\hline $\begin{array}{l}\text { Subcutaneous cysts } \\
\quad(4 \text { with seizures) }\end{array}$ & 8 & $8(100)$ \\
Epileptic seizures & 22 & $17(77.3)$ \\
"Weakness" or pain & 3 & $2(66.6)$ \\
Headache & 21 & $9(42.9)$ \\
No sign / symptoms & 71 & $16(22.5)$ \\
\hline
\end{tabular}

Source : Desowitz et al. ${ }^{4}$

The immuno-electrophoresis (CIEP) technique found that among 125 serum samples all individuals (8) with palpable subcutaneous cysticerci were serologically positive. Four among the 8 individuals with nodules had a history of seizures. Among 22 individuals with a history of seizures only $77.3 \%$ were positive, whereas $22.5 \%$ individuals without any clinical complaints were positive. ${ }^{4}$

Further investigations in this area discovered that burns and epileptic seizures were associated with cysticercosis. ${ }^{3}$ The number of patients with burns, admitted to the hospital of Enarotali markedly increased during 1973 to 1976 . Before 1973 only a few cases were hospitalized, whereas during 1973 to 1976, 157 were treated at the hospital. Among the cases with burns $62.8 \%, 33.1 \%$ and $16.6 \%$ respectively suffered from seizures, had cysticercus nodules and stool samples were positive for Taenia eggs or proglottids. Burns were associated with cysticercosis in the age group of over 11 years. In 
these groups 88 out 121 cases had epileptic seizures before or during hospitalization.

During the last years cases with taeniasis and cysticercosis were found in increasing numbers in Jayawijaya District, an area east of Paniai District. Reports of 20 local health centers in Jayawijaya District mentioned a total of 638 and 945 new cases with seizures respectively in 1994 and 1995 (Table 2). During the two years the number of death due to the disease were six and eight ${ }^{7}$. One of the local health center was in Assologaima. At this health center an increasing number of cases with seizures was recorded ${ }^{5}$. In the year 1991 only 4 cases were reported among a population of 13334 people, which meant an incidence rate of $0.03 \%$. During the years 1992,1993 , 1994 and 1995 respectively 41,68, 35 and 145 cases were recorded at the same health center. During these fours years the incidence rates were respectively 0.28 , $0.43,0.21$ and $0.83 \%$. The cysts extirpated from 14 men and 1 pig were diagnosed as cysticercus of Taenia solium.

Table 2. Number of new cases with epileptic seizures at health units (HU) in Jayawijaya District, 1994 and 1995

\begin{tabular}{lcc}
\hline Number of HU & \multicolumn{2}{c}{ Number of new cases } \\
\cline { 2 - 3 } & 1994 & 1995 \\
\hline $1-5$ & 352 & 511 \\
$6-10$ & 275 & 431 \\
$11-15$ & 11 & 3 \\
$16-20$ & 0 & 0 \\
\hline
\end{tabular}

Source : Widarso et al ${ }^{7}$

A questionnaire distributed to 31 respondents in Assologaima subdistrict revealed that $83.9 \%$ were illiterates, $93.6 \%$ farmers and all of them were sometimes eating pork, no other meat. All of them roasted the meat on hot stones (Table 3 ). The river was used as a source of drinking water by $90.3 \%$ and $90.3 \%$ admitted that they did not cook the water before drinking. Among them $64.5 \%$ did not wash their hands before eating and $58.1 \%$ after defecation. Of the respondents $64.5 \%$ defecated around bushes or in the forest. Widarso et al. ${ }^{7}$ described that none of them had toilet facilities, therefore probably the number of the respondents who are defecating promiscuously was much higher than admitted by themselves (Table 4). It was also observed that pigs were roaming around the houses, entering houses, although sometimes pigs were put behind fences.
Diagnosis of the disease was mostly based on clinical symptoms. Laboratory facilities were very limited; no radiological equipment was available such as CT. Scan.

Table 3. Identity and eating habits of 31 respondents in Subdistrict Assologaima (1996)

\begin{tabular}{lc}
\hline Identity and eating habits & $\%$ \\
\hline Illiterates & 83.9 \\
Farmers & 93.6 \\
Christians & 100 \\
Consuming pork & 100 \\
Cooking with hot stones & 100 \\
\hline
\end{tabular}

Source : Widarso et al ${ }^{7}$

Table 4. Personal and environmental hygiene of 31 respondents in Subdistrict Assologaima (\%)

\begin{tabular}{lc}
\hline Habits and environmental hygiene & $\%$ \\
\hline Source of water (river) & 90.3 \\
Drinking water (uncooked) & 90.3 \\
Not washing hands & \\
a before eating & 64.5 \\
a after defecating & 58.1 \\
Habit of defecation (bushes/forest) & 64.5 \\
No toilet facilities & 100 \\
\hline
\end{tabular}

Source : Widarso et $\mathrm{al}^{7}$

\section{INTERNATIONAL COLLABORATION}

After international collaboration was established, especially with Department of Parasitology, Asahikawa Medical College serological studies and DNA analysis could be conducted. Wandra et al. ${ }^{5}$ reported a pig from Jayawijaya, harboring multiple cysts, serologically positive, using new GP antigens for the immunoblot and ELISA method ${ }^{8,9}$. Mitochondrial DNA analysis of the material (the pigs cyst) confirmed the identification except for 3 of 391 basepairs, at 130,136 and 334 , of the CO 1 gene, while Bowles and McManus described R, R and Y, respectively. ${ }^{5}$

A total of 49 serum samples from people attending the local health unit in Assologaima were serologically examined (Table 5). Immunoblot analysis revealed that $12(67 \%)$ of 18 patients with anamnesis of seizures and $20(65 \%)$ of 31 cases with subcutaneous nodules were serologically positive for cysticercosis. ${ }^{5}$

A recent survey in other villages, i.e. Tulem, Hepuba and Siepkosi found that among 50 persons with 
immunoblot seropositive cysticercosis $68.0 \%$ suffered from clinical signs (Table 6). Table 7 shows that among 161 seropositive cases, living in these three villages, $47.50 \%$ was found in the age group of 24-32 years (international collaboration team, unpublished data).

Table 5. Immunoblot analysis of 49 serum samples from Jayawijaya District

\begin{tabular}{lcc}
\hline & Number & Seropositive (\%) \\
\hline Epileptic seizuires & 18 & $12(67)$ \\
Subcutancous nodule & 31 & $20(65)$ \\
\hline
\end{tabular}

Source: Wandra et $\mathrm{al}^{5}$

Table 6. Clinical signs of peoples in three villages of Jayawijaya District with immunoblot seropositive cysticercosis, 1998

\begin{tabular}{lcc}
\hline Clinical signs & Number & $\%$ \\
\hline Seizures, headache and cysts & 11 & 22.0 \\
Seizures and headache & 8 & 16.0 \\
Scizures and cysts & 1 & 2.0 \\
Headache and cysts & 5 & 10.0 \\
Seizures & 0 & 0.0 \\
Headache & 6 & 12.0 \\
Cysts & 5 & 10.0 \\
No signs / symptoms & 14 & 28.0 \\
\hline Total & 50 & 100.0 \\
\hline Source : International collaboration team (unpublished data)
\end{tabular}

Table 7. Immunoblot seropositive cysticercosis according to age groups in three villages of Jayawijaya District, 1998

\begin{tabular}{lcc}
\hline $\begin{array}{l}\text { Group of age } \\
\text { (years) }\end{array}$ & Number of samples & $\begin{array}{c}\text { Seropositive } \\
(\%)\end{array}$ \\
\hline $6-14$ & 8 & $2(25.00)$ \\
$15-23$ & 26 & $5(23.08)$ \\
$24-32$ & 44 & $19(47.50)$ \\
$33-41$ & 38 & $11(28.95)$ \\
$42-50$ & 25 & $9(36.00)$ \\
$\geq 51$ & 20 & $4(20.00)$ \\
\hline Total & 161 & $50(31.05)$ \\
\hline
\end{tabular}

Source : International collaboration team (unpublished data)

Sera, obtained from eight pigs from several countries, including one from Jayawijaya, Indonesia, harboring multiple cysticerci, showed very similar antibody responses as human cysticercosis. The ELISA optical density values were between 0.567 and 2500 (maximum OD), whereas those from uninfected four pigs were $0.076 \pm 0.014$. The cut-off value in human cysticercosis was $0.150 .^{9}$ These preliminary results strongly suggest that a new serodiagnostic technique using GPs purified by a preparative iso-electric focusing is most useful and reliable for both swine and human cysticercosis. ${ }^{8}$ After this preliminary study and several other studies hopefully the serodiagnosis using specific antigens purified by a single step of preparative iso-electric focusing could be used in detecting human, as well as swine cysticercosis.

At the end of 1999 a study using copro-antigens was started as a modus to detect sources of the spreading of the disease, which are persons harboring adult Taenia solium worms.

\section{CONCLUSIONS}

The high mobility of people, personal and environmental hygiene, husbandry of pigs and consuming of not well-cooked pork are important issues of the problem on taeniasis and cysticercosis in Irian Jaya Province of Indonesia. To solve the problem, health education especially for students, treatment of adult worm carriers and their families should be given high priority. These activities should be based on an integrated approach of several institutions and strong commitment of the central as well as the local government.

\section{REFERENCES}

1. Tumada LR, Margono SS. Intestinal helminthic infection in the Paniai Highlands, with special reference to Taenia and Hymenolepis nana. Madj Kedok Indon 1973a; 7-8 Madj Kedok Indon 1973a; 103-7.

2. Tumada LR, Margono SS. Cysticercosis in the area of the Wissel Lakes, West Irian. Southeast Asian J Trop Med Pub Health 1973b; 3: 371-6.

3. Subianto DB, Tumada LR, Margono SS. Burns and epileptic fits associated with cysticercosis in mountain people of Irian Jaya. Trop Geogr Med 1978; 30: 275-8.

4. Desowitz RS, Margono SS, Sutjahyo, Simanjuntak GM. Observations on the application of counterimmunoelectrophoresis for the sero-epidemiology of human cysticercosis. Southeast Asian J Trop Med Pub Health 1977; 8: 303-7

5. Wandra T, Subahar R, Simanjuntak GM, Margono SS, Suroso T, Okamoto M, Nakao Y, Nakaya K, Schantz PM, Ito A. Resurgence of cases of epileptic seizures and burns associated with cysticercosis in Assologaima, Jayawijaya, Irian Jaya, Indonesia, 1999-95. Trans Royal Soc Trop Med Hygiene 2000; 94: 46-50. 
6. Ritchie LS. An ether sedimentation technique for routine stool examination. From: Craig and Faust's Clinical Parasitology, Faust and Russel, 1964; 1948.

7. Widarso, Purba WH, Wandra T, Suroso T. Permasalahan dalam program pemberantasan taeniasis / sistiserkosis di Indonesia, khususnya di Irian Jaya. Scientific Session at KONAS V PETRI, KONAS VIII P4I and KONAS PKWI. Makassar, 1999.

8. Ito A, Plancarte A, Ma L, Kong Y, Flisser A, Cho SY, Liu YH, Kamhawi S, Lightowlers MW, Schantz PM. Novel antigens for neurocysticercosis : simple method for serodiagnosis. Am J Trop Med Hyg 1998; 58: 291-4.

9. Ito A, Plancarte A, Nakao M, Nakaya K, Ikejima T, Piao ZX, Kanazawa T, Margono SS. ELISA and immunoblot using purified glycoproteins for serodiagnosis of cysticercosis in pigs naturally infected with Taenia solium. J Helminth 1999; 73: 363-5 